Cinémas

Revue d'études cinématographiques

Journal of Film Studies

\title{
Index des titres de numéros
}

Volume 15, numéro 2-3, printemps 2005

Cinélekta 5

URI : https://id.erudit.org/iderudit/012330ar

Aller au sommaire du numéro

Éditeur(s)

Cinémas

ISSN

1181-6945 (imprimé)

1705-6500 (numérique)

Découvrir la revue

Citer ce document

(2005). Index des titres de numéros. Cinémas, 15(2-3), 219-219. d'utilisation que vous pouvez consulter en ligne.

https://apropos.erudit.org/fr/usagers/politique-dutilisation/ 


\section{Index des titres de numéros}

Américanité et cinéma

Vol. $1, \mathrm{n}^{\text {os }} 1 / 2$

\section{Cinélekta 1}

Vol. 5, n 3

Cinélekta 2

Vol. 8, n' 3

Cinélekta 3

Vol. $10, \mathrm{n}^{\circ} 1$

Cinélekta 4

Vol. 12, n 3

Cinéma et cognition

Vol. $12, \mathrm{n}^{\circ} 2$

Cinéma et mélancolie

Vol. 8, $\mathrm{n}^{\text {os }} 1 / 2$

Cinéma et musicalité

Vol. 3, $\mathrm{n}^{\circ} 1$

Cinéma et réception

Vol. 2, $n^{\text {os }} 2 / 3$

Cinéma muet au Québec et au

Canada (Le)

Vol. 6, n 1

Cinéma québécois et États-Unis Vol. 7, n 3

Critique cinématographique (La)

Vol. 6, $n^{\text {os }} 2 / 3$

Dispositifs de médiation au cinéma

(Les)

Vol. 9, $\mathrm{n}^{\circ} 1$

Dispositif(s) du cinéma (des

premiers temps)

Vol. 14, n 1

Documentaire (Le)

Vol. 4, n 2

Écrit/écran

Vol. 4, n ${ }^{\circ} 1$

Écritures dans les cinémas d'Afrique

noire

Vol. $11, \mathrm{n}^{\circ} 1$
Eisenstein dans le texte

Vol. $11, n^{\text {os }} 2 / 3$

Histoires croisées des images

Vol. $14, \mathrm{n}^{\text {os }} 2 / 3$

Imaginaire de la fin

Vol. 13, n 3

Intermédialité et cinéma

Vol. $10, \mathrm{n}^{\text {os }} 2 / 3$

Limite(s) du montage

Vol. $13, \mathrm{n}^{\text {os }} 1 / 2$

Nouveau cinéma chinois (Le)

Vol. 3, $\mathrm{n}^{\text {os }} 2 / 3$

Nouvelles technologies : nouveaux cinémas?

Vol. 1, n 3

Paysage au cinéma (Le)

Vol. 12, $\mathrm{n}^{\circ} 1$

Questions sur l'éthique au cinéma

Vol. 4, $\mathrm{n}^{\circ} 3$

Représentation du corps au cinéma (La)

Vol. 7, n ${ }^{\text {os }} 1 / 2$

Scénario (Le)

Vol. 2, $\mathrm{n}^{\circ} 1$

Scénarios fictifs (Les)

Vol. 9, n ${ }^{\text {os }} 2 / 3$

Temps au cinéma (Le)

Vol. $5, \mathrm{n}^{\text {os }} 1 / 2$ 